\title{
DOSAGE EFFECTIVENESS OF MANURE AND PLANTING DISTANCE ON THE GROWTH AND PRODUCTION OF PEANUTS (ARACHIS HYPOGAEA, L)
}

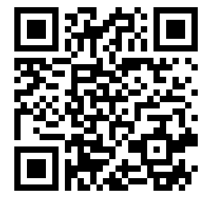

\author{
Hari Soeseno Hardjoloekito ${ }^{* 1}$ 四 (iD) \\ ${ }^{* 1}$ Lecturer of Agroteknologi University Soerjo Ngawi, Indonesia
}

DOI: https://doi.org/10.29121/granthaalayah.v8.i8.2020.861

Article Type: Research Article

Article Citation: Hari Soeseno

Hardjoloekito. (2020). DOSAGE

EFFECTIVENESS OF MANURE AND

PLANTING DISTANCE ON THE GROWTH AND PRODUCTION OF

PEANUTS (ARACHIS HYPOGAEA, L).

International Journal of Research -

GRANTHAALAYAH, 8(8), 200-206.

https://doi.org/10.29121/granthaa

layah.v8.i8.2020.861

Received Date: 25 July 2020

Accepted Date: 28 August 2020

Keywords:

Peanuts

Pertilizer

Spacing

\section{ABSTRACT}

This study aims to identify and study the effect of plant spacing and chicken manure fertilizers on growth and yield of peanut. This research was conducted at the Experimental Farm of the Faculty of Agriculture Land Dictionary Universitas Soerjo Ngawi, East Jawa , took place from Desember 2019 to March 2020 .The method used is a plot design Separated (Split Plot Design) with nine combinations of treatments and three replications. The main plot (main plot) is a spacing (A), J1 $20 \mathrm{~cm} \times 20 \mathrm{~cm}, 30 \mathrm{~cm} \times 20 \mathrm{~J} 2$ $\mathrm{cm}$, J3 $40 \mathrm{~cm} \times 20 \mathrm{~cm}$, as a subplot (sub-plots) is the dose of compost (P), P1 5 tons / ha, P2 10 tons / ha, P3 15 tons / ha. Parameters observed that plant height $(\mathrm{cm})$, number of primary branches (branch), the overall weight of pod (g), number of pods containing (pod), the number of empty pods (legumes), berangkasan wet weight (g), dry berangkasan weight (g), 100 seed weight (g).Based on the results of analysis of variance showed that the spacing of chicken manure fertilizer rate and not significant for all variables observed. Treatment interaction effect was not significant on all observed variables, but the variables significantly.

\section{INTRODUCTION}

Peanut development efforts are increasingly gaining attention, along with an increase population and total per capita income and public awareness on nutritious food menu. This causes the need of Peanuts to increase by approximately $7.5 \%$ per year (Suprapto, 1985).

Peanuts are a great source of protein, meaning that for the health of the development of the human body, it will especially be felt in countries where protein consumption is still low.

The biological value of protein is quite high with protein content of between 30 to $50 \%$, close to the value of cow's milk protein. Fat content between 15 to $20 \%$, in addition it also contains vitamins A, B, C and D (Samsudin, et al., 1985).

Peanuts in addition to being useful to meet the nutritional needs of the body, are also efficacious as a cure for several types of diseases. The results of research in the United Kingdom shows that Peanuts are effective in preventing cancer and coronary heart disease. The emergence of cancer in the body due to nitrosamine compounds. Peanuts contain two important compounds, namely phenolic and unsaturated fatty acids. Both of these compounds can suppress the appearance of nitro-samin compounds, so that it functions as an antidote to cancer. In addition,

(C) 2020 The Author(s). This is an open access article distributed under the terms of the Creative Commons Attribution License, which permits unrestricted use, distribution, and reproduction in any medium, provided the original author and source are credited. 
Dosage Effectiveness of Manure and Planting Distance on The Growth and Production of Peanuts (Arachis Hypogaea, L)

lecithin levels in Peanuts can destroy fat deposits in the body, so that indirectly, can suppress the onset of high blood pressure and diarrhea (Rukmana and Yuniarsih, 1996).

Peanuts productivity in Indonesia is still very low be compared with peanut producing countries, among others: America, China, Brazil and Japan (Purwoko, 1994). Peanut in optimum condition can reach 2.5 tons / ha (Manwan et al., 1991). The national average yield of Peanuts is still below $50 \%$ of the optimum yield, which is 0.7 to 0.8 tons / ha (Sumarno et al., 1989).

In Indonesia, of the many types of beans, peanut ranks second after soybean. This certainly has the potential to be developed because it has high economic value and large domestic market opportunities (Rachman, 2007). According to Adisarwanto and Wudianto (2002), Indonesian peanut production is still relatively low, because to meet national needs we have to import from outside, while the productivity of peanuts in our country reaches 2 tons / ha.

Groundnut plants (Arachis hypogaea L.) which have been spread and planted in Indonesia are actually not native plants, but plants originating from the American continent, precisely in the area of Brazil (South America). This peanut plant is expected to enter Indonesia between 1521-1529. This plant is broght by the Spaniards who conduct shipping and trade between Mexico and the Maluku Islands (Adisarwanto, 2001). Peanut is one of the economic and strategic food crop commodities in an effort to increase income and improve people's nutrition. Peanuts have an important value for economic growth in Indonesia. The role of peanuts is seen by the increasing demand in the country and the diversity of processed products be made from peanuts produced by home-based industries as well as medium and large industries. But the ironic thing is that peanut production per hectare in Indonesia is still low

According to Suprapto (2004), the cause of the low production of peanut plants is due to several factors, namely: less optimal soil cultivation, less optimal planting, crop maintenance, low seed quality, and drought. To overcome these obstacles need to be done a variety of efforts are taken. The business includes improving how to plant. The use of varieties, regulation of plant populations, the use of fertilizers with the right dosage.

Regulation of plant population is essentially a regulation of planting distance that influences on competition in the absorption of nutrients, water and sunlight, so that if not properly regulated it will affect crop yields. Planting Distance in dense cause it to happen competition of intra-species and inter-species. The main competition is competition in obtaining light, nutrients and water (Suprapto, 2003).

Arrangement of planting spacing with a certain density aims to give growth space to each plant so that it grows well. Plant spacing will affect the efficiency of light efficiency, competition between plants for water use and nutrients so that it will affect crop production (Hidayat, 2008). One effort that can be done to overcome this is by setting spacing. A tight planting distance will increase the competitiveness of plants against weeds because plant canopy inhibits the exposure of light to the land surface so that weed growth is inhibited, as well as the rate of evaporation can be suppressed.

Planting distance that is too narrow may result in crop cultivation that will produce relatively less due to competition between the plants themselves. Therefore, optimum planting spacing is needed to obtain maximum yield (Pitijo, 2009). Planting with regular spacing is aimed at making each plant obtain nutrients from the same soil, air, and sunlight requirements (Sutrisno, 2004).

Based on Joseph's research (2005) the spacing of $40 \mathrm{~cm} \times 20 \mathrm{~cm}$ gives the best effect on the growth and production of peanut plants. According to Adisarwanto (2001), One of the causes of the low productivity of peanuts is because of the low levels of organic matter in the soil. Organic fertilizers are the best and most natural soil enhancer than artificial fixers. Furthermore, according to Sutanto and Rachman, (2012), in general organic fertilizers contain low levels of N, P, K macro nutrients, but contain sufficient amounts of micro nutrients which are very much needed for plant growth. The use of manure functions to improve the physical and biological structure of the soil, increasing the soil's absorption of water.

Giving manure has an effect on increasing Al-dd and reducing $\mathrm{pH}$, this is because organic matter from manure can neutralize the acidity of the soil. Manure will also donate a number of nutrients into the soil that can function to support growth and development, such as N, P, K (Wulandari, 2011) The results of research by Suwardjono (2001) and Samuli, et al (2012), show that the application of chicken manure can increase the number of filled peas in peanuts and the treatment of 10 tons ha- 1 gives the best growth results for peanut crop production.

Based on the description above, it is necessary to conduct research on the effect of planting distance and dosage of chicken manure on the growth and production of peanut plants (Arachis hypogaea L). This study aims to 
determine, study and obtain the effect of planting distance and the dose of chicken manure on the growth and production of peanut (Arachis hypogaea L.).

\section{MATERIALS AND METHODS}

The research was carried out in the Experimental Field of Campus C, Faculty of Agriculture, University of Soeorjo Ngawi, taking place from December 2019 to March 2020.

The materials used in this study were giraffe varieties of peanut seeds, chicken manure. The tools used water pumps, torches, hoes, stakes, meters, rapia ropes, machetes, sprayers, scales, stationery, and nameplate. This study uses a split plot design with 9 treatment combinations that were repeated 3 times. The treatment factors referred to are as follows:

1) Plot are Planting Distance (J)

J1: $20 \mathrm{~cm} \times 20 \mathrm{~cm}$

J2: $20 \mathrm{~cm} \times 30 \mathrm{~cm}$

J3: $20 \mathrm{~cm} \mathrm{x} 40 \mathrm{~cm}$

2) Child plots are Dose of Chicken Manure Compost (P)

P1: 5 ton $/$ ha $(1,5 \mathrm{~kg} /$ petak $)$ plot

P2: 10 ton/ha (3 kg/petak)

P3: 15 ton/ha $(4.5 \mathrm{~kg} /$ petak)

The variables observed in this study include:

1) Plant height $(\mathrm{cm})$,

2) Quantity of primary branches (branches),

3) Overall Weight of pods (g),

4) Quantity of filled pods per plant (g),

5) Quantity of empty pods per plant (g),

6) Dry Trimming Weight (g), 7). Weight of 100 seeds (g).

\section{RESULTS AND DISCUSSIONS}

\subsection{RESULT}

Based on the results of diversity analysis in Table 1 . shows that the treatment of planting distance have no significant effect on all variables observed. The interaction treatment did not significantly affect all observed variables, but it did significantly affect the plant height and the number of empty pods.

Table 1: Results of Analysis of Diversity Effect of Planting Distance and hicken Manure on Observed Variables

\begin{tabular}{|l|l|l|l|l|l|}
\hline Observed Variables & \multicolumn{3}{|l|}{ Treatment } & Efficient Diversity (\%) \\
\hline & J & P & I & \\
\cline { 2 - 6 } & tn & tn & $*$ & 3,47 \\
\hline Quantity of Primary Branch (stalk) & tn & tn & tn & 8,28 \\
\hline Total weight of pods (g) & tn & tn & tn & 21,38 \\
\hline Quantity of pods filled (pods) & tn & tn & tn & 17,32 \\
\hline Number of empty pods (pods) & tn & tn & $*$ & 31,28 \\
\hline Weight 100 seed (g) & tn & th & tn & 7,14 \\
\hline Dry weight (g) & tn & tn & tn & 23,75 \\
\hline
\end{tabular}

Information

tn $=$ No real effect

$*$ real effect

$\mathrm{J}=$ Plant Distance

$\mathrm{P}=$ Dosage of chicken manure

$\mathrm{I}=$ Interaction discussion 
Dosage Effectiveness of Manure and Planting Distance on The Growth and Production of Peanuts (Arachis Hypogaea, L)

\section{DISCUSSION}

Based on the results of the soil analysis before planting in the Nuclear Biology and Chemical Laboratory of the Army Directorate (2014), it was shown that the land used in this study was classified as acid (pH H2O $=4.60)$ with a high cation exchange capacity $(22.99 \mathrm{cmol}(22,99 \mathrm{cmol}(+) \mathrm{kg}-1)$, the content of C-organic of $8.36 \%$ is classified as very high, the $\mathrm{C} / \mathrm{N}$ ratio of 22.00 is classified as high, the content $\mathrm{N}$-total is classified as low (0.38\%) and the available $\mathrm{P}$ is relatively high (56.48 mg kg-1), exchanged bases such as Ca-dd $4.69 \mathrm{cmol}(+) \mathrm{kg}-1 \mathrm{are} \mathrm{low}, \mathrm{Mg}-\mathrm{dd} 0.29 \mathrm{cmol}(+)$

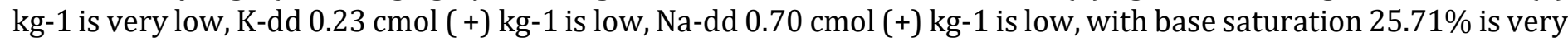
low, Al-dd $0.82 \mathrm{cmol}(+) \mathrm{kg}-1$.

The soil is used in this study included in the category of low soil fertility with pH $\mathrm{H} 2 \mathrm{O}$ classified as acidic with a low total $\mathrm{N}$-content. Likewise with the available $\mathrm{P}$, although its availability is high, but the available $\mathrm{P}$ is widely absorbed by metal ions in the soil such as aluminum, so that the Al-P is formed and can cause P to be absorbed by the peanut plant.

The provision of chicken manure can improve soil fertility (physical, chemical and biological) and can provide nutrients who have been needed by plants. This is in line with the opinion of Wulandari (2011), organic manure has an important function for the soil, which is to blow up surface soil layers, increase the population of soil microorganisms, enhance absorption and water retention power which as a whole will increase soil fertility.

Furthermore Hardjowigeno (1995) states that the role of organic matter in the soil is to improve soil structure, increase cation exchange capacity, provide nutrients, improve the ability of the soil to retain water and increase the biological activity of the soil so that plants can grow and produce well. Research results treatment spacing of $20 \mathrm{~cm}$ x $40 \mathrm{~cm}$ provides the best vegetative growth of peanut plants. This can be seen in the plant height of $51.16 \mathrm{~cm}$ with the number of primary branches 6.96 branches. It is assumed that the spacing can grow and develop well without experiencing much competition in getting sunlight, water and nutrients. This is in line with the opinion of Suprapto (2004) that plant spacing basically plants can grow and develop well without experiencing much competition in taking nutrients, water and sunlight that can occur with dense spacing.

Treatment of planting distance of $20 \mathrm{~cm} \times 20 \mathrm{~cm}$ shows the lowest plant height that is $50.07 \mathrm{~cm}$. This is due to more plant populations so that competition occurs in fighting over nutrients, water and light. In line with Husna (2013), which states that a dense population will cause competition between plants against sunlight and growing space so that it affects morphology such as plant height. The results showed the dose of chicken manure at 10 tons / ha ( $3 \mathrm{~kg} / \mathrm{plot})$ gave the best effect on the vegetative growth of peanut plants.

The treatment of chicken manure at 10 tons/ha $(3 \mathrm{~kg} / \mathrm{plot})$ showed the highest growth, it was seen from the height of the plant $(51.22 \mathrm{~cm})$ and the number of branches ( 7.13 branches). This is because the treatment of chicken manure compost at a rate of 10 tons has been able to provide adequate and balanced nutrients to support the vegetative growth of plants. In line with Agustina (1990), that the availability of adequate and balanced amount of nutrients is the main factor that determines the success rate of plant growth and production. give low growth to the vegetative growth of peanut plants. This is indicated by the low plant height $(50.07 \mathrm{~cm})$ and the number of primary branches ( 6.50 branches).

The low level of growth and production produced due to the provision of chicken manure 5 tons $/ \mathrm{ha}(1.5 \mathrm{~kg} /$ plot) has not been able to provide sufficient and balanced nutrients to support the growth and production of peanut plants in order to grow optimally. In line with the opinion of Wijaya (2008), Dwijoseputro (1992) states that without the availability of sufficient and balanced macro and micro nutrients the plants will show symptoms of nutrient deficiency resulting in disturbed plant growth and plants will flourish if nutrient needed for planting is available in quantities sufficient and balanced.

Interaction between planting distance $(20 \mathrm{~cm} \times 40 \mathrm{~cm})$ and 10 tons/ha of chicken manure compost ( $3 \mathrm{~kg} / \mathrm{plot})$ produced the best growth. This shows that this combination of treatments is able to provide the space and nutrients needed by plants for the growth of peanut plants. Djuarnani (2005), which states that soil conditions (physical properties, chemical and biological of the soil) are very important for plant growth and production is the availability of adequate and balanced nutrients. Marsono and Sigit (2002), stated that the addition of organic matter can improve the structure of the soil to make it more loose so that soil aerase is good and is able to provide nutrients needed by plants during the growth phase.

Besides the addition of organic matter can increase the activity of soil microbes that can be symbiotic with Rhizobium bacteria found in the root nodules of peanut plants can fix nitrogen from the air so that it can increase 
the availability of nitrogen in the soil. While the lowest interaction was found in the treatment of $20 \mathrm{~cm} \times 20 \mathrm{~cm}$ spacing and chicken manure 5 tons / ha $(1.5 \mathrm{~kg} / \mathrm{plot})$. This is indicated by the low growth rate of peanut plants. Wijaya (2008) states that the low growth rate that is produced is due to planting distance that is too narrow and the compost given cannot provide adequate and balanced nutrients. Without adequate and balanced availability of macro and micro nutrients, plants will show symptoms of nutrient deficiency which will result in disturbed plant growth.

Treatment of planting distance $20 \mathrm{~cm} \times 40 \mathrm{~cm}$ gave the best results compared to other treatments. This is reflected in the overall weight pod variable (73.57 g), wet stew weight (315.65 g), dry stew weight (58.31 g). This is due to the wider planting distance, the greater the sunlight received that can be used by plants for the process of photosynthesis and the wider the possibilities for plant growth so that the wider planting distance will be more. As stated by Koswara (1982) in Arfiani (2004), that the density of planting/planting distance affects the plant population and the efficiency of the use of light. In addition, the appropriate planting distance will reduce competition between plants in using water and nutrients so that it affects yield. Furthermore Sunaryono and Rismunandar (1990), stated that to live plants need water, air, sunlight and nutrients.

One of the causes of high production is because of the wide planting distance which allows plants to fall so that the gynophore that penetrates more planting and produces more pods. While the treatment spacing of $20 \mathrm{~cm} \times 20$ $\mathrm{cm}$ shows low production this can be seen from the low yield total pods (67.05 g), number of filled pods (34.01 pods), wet stew weight (265.72 g), dry stew weight (53.49 g). This is due to the lack of sunlight needed by plants and the competition between plants in fighting over nutrients causing the production of plants to be low.

In line with Hidayat (2008), which states that plantinf distance will affect the efficiency of light efficiency, competition between plants for water use and nutrients so that it will affect crop production. best production. The results showed that the treatment of chicken manure dose of 10 tons / ha ( $3 \mathrm{~kg} / \mathrm{plot}$ ) gave the best production. This can be seen in the observations of overall pod weight $(73.24 \mathrm{~g})$, number of pods containing 37.35 pods, wet berangksan weight (311.52 g), dry berangkangan weight (61.92 g). This shows that increasing the dose of fertilizer increases the production of peanut plants. This happens because the increase in fertilizer dosage means the availability of nutrients that are used by more plants, in accordance with the growing conditions of peanut plants that require fertile soil, so that plants can utilize nutrients in the soil for plant growth and production.

In line with the opinion of Sugito et al (1995), it states that the use of organic manure provides several benefits such as supplying macro and micro nutrients, increasing the soil organic matter content so as to improve the ability of the soil to retain water and increase soil porosity and increase microorganism activities in the soil. Thus the addition of organic material can loosen the soil. In the loose soil conditions, it is needed to make it easier for the ginofor to penetrate the soil. Wijaya continued (2008), stating that the provision of organic matter in providing nitrogen, potassium, calcium, and the availability of phosphorus which dissolves easily in the soil is sufficient for plants to develop pods.

The treatment of chicken manure 5 tons / ha gives the lowest production. This can be seen in the observations of overall pod weight (69.24 g), number of pods containing 33.35 pods, wet wet weight (290.22 g), dry dry weight (51.84 g). This is due to the availability of nutrients in the soil remains low, and resulted in stunted growth of peanut plants so that the needs of plants have not been met and also the nature of manure that is slowly available. By treatment the planting distance of $20 \mathrm{~cm} \mathrm{x} 20 \mathrm{~cm}$ and the dose of chicken manure 10 tons / ha gives the best results. Although the results of planting distance $20 \mathrm{~cm} \times 40 \mathrm{~cm}$ gives the best results but because the population of planting distance $20 \mathrm{~cm}$ x $20 \mathrm{~cm}$ more, causing more production / ha.

The results section should provide details of all of the experiments that are required to support the conclusions of the paper. The section may be divided into subsections, each with a concise subheading.

It is advised that this section be written in past tense. It is a good idea to rely on charts, graphs, and tables to present the information. This way, the author is not tempted to discuss any conclusions derived from the study. The charts, graphs, and table should be clearly labeled and should include captions that outline the results without drawing any conclusions. A description of statistical tests as it relates to the results should be included. 
Dosage Effectiveness of Manure and Planting Distance on The Growth and Production of Peanuts (Arachis Hypogaea, L)

\section{CONCLUSIONS AND SUGGESTION}

\subsection{CONCLUSION}

Treatment plant distance $20 \mathrm{~cm} \times 20 \mathrm{~cm}$ by tabulation gives the highest result on the growth and production of peanut plants.

The dosage of 10 tons / ha of chicken manure ( $3 \mathrm{~kg} /$ plot) by tabulation provides the best influence on plant growth and production peanuts.

Tabulation of $20 \mathrm{~cm} \times 40 \mathrm{~cm}$ spacing gives crop production the highest.

Interaction of planting distance of $20 \mathrm{~cm}$ x $20 \mathrm{~cm}$ and the dose of chicken manure 5 ton / ha ( $3 \mathrm{~kg} / \mathrm{plot})$ by tabulation gives the highest result on growth and production of peanut plants.

\subsection{SUGGESTION}

In peanut cultivation, arrangement of planting distance and dosage of manure need to be considered to produce peanut plants that have good vegetative growth and good production results. Based on the results of this study recommend a spacing of $20 \mathrm{~cm} \times 20 \mathrm{~cm}$ and a dose of manure 10 tons / ha.

\section{SOURCES OF FUNDING}

This research received no specific grant from any funding agency in the public, commercial, or not-for-profit sectors.

\section{CONFLICT OF INTEREST}

The author have declared that no competing interests exist.

\section{ACKNOWLEDGMENT}

None.

\section{REFERENCES}

[1] Adisarwanto dan R. Wudianto. 2002. Increase Peanut Production in Rice Fields and Dry Land. Penebar Swadaya. Malang

[2] Adisarwanto. 2001. Increasing Peanut Production in Rice Fields and Land Dry. Jakarta.

[3] Arfiani W. B. 2004. Response Growthing and Yield of Soybean in Tungpangsangkan with corn on arrangement of the planting time and planting distance. Amir Hamzah University of Medan. Medan

[4] Balitkabi. 2012. Bulletin of the Directorate of Nuts and Bulbs Cultivation of the Moon Period September 2012. Ministry of Agriculture.

[5] Djuarnani S., Kristian B dan S. Setiawan. 2005. How to Quickly Make Compost. Agromedia Pustaka. Jakarta

[6] Dwijoseputro. 1992. Physiology and Plant Metabolism. Gramedia. Jakarta.

[7] Hidayat N. 2008. Peanut growthing and production (Arachis hypogaea L.) Variety of Local Madura at planting distance and dosage of phosphorus manure. Faculty of Agriculture of Trunojoyo University. Madura.

[8] Harjowigeno, S. 1995. Geology. Fakulty of Bogor Agricultural University. Bogor.

[9] Husna, A. 2013. The Effect of planting distance on Plant Growthing and Production Shallot (Allium ascalonicmL). Faculty of Agriculture of Muhammadiyah university of West Sumatera. Sumatera Barat

[10] Marsono dan Sigit P. 2002. Type of Manure and Its Applications. Penebar Swadaya. Jakarta.

[11] Pitojo, S. 2009. Peanut Seeds. Kanisius. Yogyakarta

[12] Rachman, M. 2007. Cultivate peanuts. Penebar Swadaya. Jakarta. 


\section{Hari Soeseno Hardjoloekito}

[13] Samuli O., La K., Laode S., 2012. Soybean production (Glycine maxL.Merrill) on Various Dose of Cow Manure bokashi. Research of Agronomy.

[14] Suprapto, H. S. 2004. Cultivate peanuts. Penebar Swadaya. Jakarta.

[15] Suprapto. 2003. Cultivate peanuts. Penebar Swadaya. Jakarta.

[16] Sutanto dan Rahmat. 2012. Organic Agriculture Applications. Kanisius. Yogyakarta

[17] Sutrisno. 2004. Study of Dose of Manure and Planting Distance of Peanuts. Research Report. Research and Development Office of Pati Regency.

[18] Effect of several types of manure on peanut growthing and Production. Mathematical, Science, Technology Journal,

[19] Suwardjono. 2001. The Effect of several types of manure on peanut growthing and Production. Mathematical, Science, Technology Journal.

[20] Sugito, Yogi, Y., Nuraini dan E. Nihayati. 1995. Organic Agriculture System. Fakulty of Agricultural. Brawijaya Universitas of Malang. Malang.

[21] Wulandari, V. 2011. The Effect of Giving Several Doses of Chicken Manure on Plant Growthing and Yield of Rosella (Hibiscus sabdariffaL.) at Ultisol Soil. Thesis, Faculty of Agriculture, Andalas University of Padang.

[22] Wijaya, K. A. 2008. Nutrition of plant. Prestasi Pustaka. Jakarta.

[23] Yusuf, M. 2005. The Effect of planting distance on Plant Growthing and Yield of Peanuts (Arachis hypogaea L.) On the Tumpangsari System with Cassava (Manihot esculenta crantz). Research Journal. 